\title{
Reflections on the Suitability and Unsuitability of English as a Foreign Langauge Teaching and Learning Styles in Benin
}

Hounnou Azoua Mathias ${ }^{1 *}$

${ }^{\mathrm{T}}$ Department of Anglophone Studies Faculty of Letters, Arts and Human Sciences University of Parakou, BP 123, Parakou, Benin

\section{Article History \\ Received: 16.09 .2021 \\ Accepted: 25.10 .2021 \\ Published: 08.01.2022 \\ Journal homepage: \\ https://www.easpublisher.com}

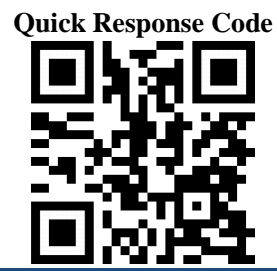

Abstract: For a successful teaching-learning process, both teachers and learners should agree about the styles to use. The present research work aimed at investigating suitability and unsuitability of EFL teaching-learning styles in public secondary schools in Parakou municipality (Benin). Three hundred and fifty (350) EFL learners and thirty five (35) EFL teachers were randomly selected for the study. Questionnaires and interviews had been the major instruments for data collection. Statistical analysis carried out with $\mathrm{R}$ 4.0.2 revealed significant mismatch between the two styles. It was noted that most of learners are likely to prefer to learn English language with the help of visual and kinesthetic materials than auditory. Teachers strongly favored kinesthetic teaching style (14.9), visual style (13.6) and disfavored auditory teaching style (12.9). The majority of them have two teaching styles (70\%). Meanwhile, it was shown that such unsuitability has important negative impacts on students such as stress, unhappiness, boredom and makes teaching-learning failed. Keywords: Suitability, Unsuitability, English, styles, Benin.

Copyright (C) 2022 The Author(s): This is an open-access article distributed under the terms of the Creative Commons Attribution 4.0 International License (CC BY-NC 4.0) which permits unrestricted use, distribution, and reproduction in any medium for non-commercial use provided the original author and source are credited.

\section{INTRODUCTION}

Nowadays, English has become an international language. It is a key language used as communication means among people of different countries. In many working spheres (science research, engineering, technology, studies, politics, business, media, advertising, etc.), English knowledge appears to be unavoidable (Mappiasse \& Sihes, 2014). The language has become so important that many governments of non-English countries introduced its teaching from basic schools. Many kindergartens and primary schools, public or private teach English to their learners. Because teaching it from early childhood enable student to speak it smoothly. By the way, English became a foreign language for learners who are mostly non-native.

In many French speaking countries, English serves for many purposes. For that reason, EFL learning and acquisition represent a challenge to face. To Anderson (1995); Arshad and al. 2012; Gan, (2013) and Alaraj (2016), English as a Foreign Language (EFL) learners faces problems and difficulties which should be taken into consideration when dealing with the whole process of EFL teaching/learning. Noonan (2005) states that college students in China are faced with difficulties concerning learning EFL and they always ask a reoccurring question about the way they can improve their English. Moreover, Visser and al. (2006); Zhou (2011), Suntonrapot and Auyporn (2013); Damrongpanit (2014) thought that a learner's achievement in any class is determined by factors such as native ability and the level of congruence between learners' learning styles and teachers' teaching styles. In such conditions, students cannot learn effectively when instructional delivery does not match their preferred learning styles. In that respect, there is the need for students to become more resourceful and find an efficient manner of learning in order to enhance their performances and achievements.

This research work aimed at focusing on the examination of the relation existing between teaching and learning styles in the context of EFL study in Parakou secondary schools.

\section{Problem statement}

Language learning and teaching is a complex system, mainly to beginners and non-experimented teachers. Whatever, novice teachers will face a daunting task on coping with new roles and responsibilities due to transitioning from student-teachers into in-service teachers (Kasim and Abdurajak, 2018). Faryadi (2012) indicated that the functions of teaching and learning theories are to assist students on how to learn effectively as it can be used as a guide to teacher to use a range of methods of designing instruction and 
teaching methodology. According to Renzulli \& Smith (1984), the knowledge of one's own learning style is essential in the learning process and makes EFL learning and teaching successful.

However, it's remarked that many English teachers do not take students' learning styles into account in their ways of teaching. A survey done by Reid (1995) cited by Abbas (2012b) showed that $90 \%$ of secondary schools teaching in USA is turned toward auditory learners. McKeachie (1995) argued that too many teachers think of students as a featureless mass; too many rarely vary their teaching methods, thinking that the method by which they were taught is best for everyone. So, it's very tough for many learners to be excellent despite their efforts of studying lessons.

This situation is similar in Benin country where larger EFL teachers still are mismatch between teaching method and learners' needs. The problem persisted over the years till now and it's important to study it deeply in order to reach appropriate solutions.

\subsection{Research questions and hypotheses}

\subsubsection{Research questions}

The research aimed to answer following questions:

- What are the learning styles of learners in the process of EFL learning?

- What are the teaching styles of teachers in the process of EFL teaching?

- Do EFL learning and teaching style suit?

\subsubsection{Hypotheses}

This work aims to investigate Reid (1987) two major hypotheses about learning styles. They are:

- H1: All students have their own learning styles and learning strengths and weaknesses.

- H2: An unsuitability between teaching and learning styles causes learning failure, frustration and demotivation.

- H2: The EFL learning and teaching styles do not suit for the goal requirements.

\section{LITERATURE REVIEW \\ 2.1. Conceptual clarification}

\section{- $\quad$ Styles}

According to Bokyung and Haedong (2014), language learning styles are "one's general approach to learning a language. Oxford distinguished learning styles from learning strategies in that the "learning strategies are more likely specific thoughts or practices learners apply to facilitate their language learning". According to Abbas (2012a), learning style is defined as "the characteristic cognitive, affective, social, and physiological behaviors that serve as relatively stable indicators of how learners perceive, interact with, and respond to the learning environment".
Then, one can conclude that learning styles include not only the cognitive domain, but also the affective and physiological characteristics, often not perceived and consciously used by learners.

On the other hand, the term style is also related to the teaching process. According to Tahereh and al. (2017), teaching style reflects a teacher's personal behaviors and media used to transmit data to or receive it from his/her students; is behaviors of teachers in their relationships with their students (Grasha, 2002); is reflection of an amalgamation of teachers' theoretical assumptions and actual teaching practice" (Kazemi and Soleimani, 2016).

\section{- Learning Approaches}

Approaches are derived from perceptions of a task and cognitive strategies that learners might then adopt to tackle it. According to Entwistle and al. (2001), there are three approaches of learning naming: deep approach, surface approach and strategic approach. Drawing on Marton and Säljö's ideas about deep and surface learning (1976), Entwistle (1979) argued that if students have a sophisticated conception of learning and a rich understanding of the nature of knowledge and evidence, they adopt a deep approach in order to reach their own understanding of material and ideas. If, on the other hand, they see learning as memorizing or acquiring facts, and their intention is merely to meet course requirements or to respond to external injunctions, they are likely to adopt a surface approach. However, students do not only adopt deep and surface approaches. The structure of a curriculum and the demands of summative assessment exert a strong influence on approaches to learning. Entwistle (1976) supported that summative assessment in higher education usually encourages a strategic approach where students combine deep and surface approaches in order to achieve the best possible marks.

\section{- $\quad$ Strategies}

Because of its significance in learning process, a great number of researchers have formulated their own definitions of the term "Strategies'. According to Pezhman (2012), learning strategies are "specific actions taken by the learner to make learning easier, faster, more enjoyable, more self-directed, more effective and more transferable to new situations. (Oxford, 1990); defines it as processes which are consciously selected by learners and which may result in actions taken to enhance the learning or use of a second or foreign language through the storage, retention, recall, and application of information about that language. For Cohen, (1990), it is intentional behavior and thoughts that learners make use of during learning in order to better help them understand, learn, or remember new information. 
Hence, learning strategies were seen as special ways of processing information that improve comprehension, learning, or retention of the information. The literature showed that the different attempts of categorizing language learning strategies reflect no fundamental changes. As the one of the most applicable definitions which has been cited most frequently in the literature was provided by Oxford, her classification of language learning strategies will be presented. She divided language learning strategies into two main categories, direct and indirect strategies which are also subdivided into six classes which are Memory strategies, Cognitive strategies, Compensation strategies, Metacognitive strategies, Affective strategies and Social strategies.

\subsection{Relation between teaching and learning styles}

Literature review revealed that some authors support there should be a match between learning styles and teaching styles whereas others think the match between the two styles has no effect on learners' performances. According to Abbas (2012a), the majority of teachers teach the way they learn. This is because they have experienced an academic success in learning environments that were instructor-centered. So, they tend to repeat with learners what worked with them and there may still be a noticeable mismatch between the learners' and the teachers' styles.

Actually, the findings of past studies stated that a learner's achievement in any class is determined by factors such as native ability, and the level of congruence between learners' learning styles and teachers' teaching styles. Felder and Dietz (2002), found that matching teaching styles to learning styles has a positive impact on achievement and satisfaction. Felder and Spurlin (2005) went along side finding that, when mismatches exist between learning styles of most students in a class and the teaching style of the professor, students may become bored and inattentive, do poorly on tests, get discouraged about the courses, the curriculum, and themselves, and in some cases change to other curricula or drop out of school. The same opinion is shared by others learning style experts. Woolhouse and Blaire (2003), Ford and Chen (2008) and Zhang (2006) showed that students will learn more and will enjoy the class experience and environment when they can use their preferred learning styles. In fact, students are blamed when the classroom activity is not compatible with their way of learning. So, they suggested that teaching and learning styles should become one of the greatest interests of the educators. In conclusion, mismatches often happen and have bad impacts on students' learning and attitudes.

Nevertheless, other researchers have found little or no evidence that matching teaching styles to learning styles improves the learning outcome (Terry, 2001 and Woolhouse, 2003) and Blaire (2003). According to Pashle (2009), there is no evidence that identifying a student's learning style produces better outcomes, and there is significant evidence that the widespread "meshing hypothesis" (that a student will learn best if taught in a method deemed appropriate for the student's learning style) is invalid.

Moreover, a third group of researchers think learners need to be able to adjust their learning styles, to become better all-around by investing extra effort in underdeveloped or underutilized styles. For instance, Hayes J. and Allinson C. W. (1997) contend that exposing learners to learning activities that are mismatched with their preferred learning style will help them develop the learning competencies necessary to cope with situations involving a range of different learning requirements.

\section{METHODOLOGY}

The present research work has been carried out in Parakou municipality in North of Bénin. Located in Borgou district in north of Benin, Parakou is situated between $9^{\circ} 21^{\prime}$ of latitude North and $2^{\circ} 36^{\prime}$ of longitude East (Afrique Conseil, 2006). It is bordered in south, east and west by Tchaourou municipality and in North by N'Dali municipality (Azoua Hounnou, 2020).

\section{1. Sampling and target population}

The sample consisted of forty-one EFL learners from the OKEDAMA secondary school. Learners were selected randomly from different classes. Ten English teachers were also involved in the study. They are selected basing on their willingness to participate to the study.

\section{2. Data collection instruments}

The study employed survey method and questionnaires and interviews were used as research instruments. EFL learners' questionnaires were made up with Reid's categorizations of learning styles and her Perceptual Learning Style Preference Questionnaire (PLSPQ). According to Reid (1987), the mean scores of the preferred learning styles can be categorized as follows: 13.5 and above (major learning style), 11.5013.49 (minor learning style), 11.49 or less (negligible learning style). The questionnaire assessed preferred learning styles of the students basing on how they learn best using their perceptions: visual, auditory, kinesthetic, tactile, group and individual preferences. This instrument was easy to administer, to interpret, self-scoring, and has reliability and validity supported by the research. PLSPQ consists of thirty question items, and each of the six learning styles is related to the five question items but for the purpose of this study, the work is done with the fifteen questions related to visual, auditory, kinesthetic learning styles. According to LdPride, (2009) cited by Abbas Pourhosein (2012), visual, auditory, kinesthetic learning styles are described as following: 
Table: Definitions of visual, auditory, kinesthetic learning styles

\begin{tabular}{|l|l|}
\hline Learning styles & Definitions \\
\hline Visual learners & $\begin{array}{l}\text { learn best in visual images } \\
\text { have a preference for seen or observed things, including pictures, diagrams, } \\
\text { demonstrations, displays, handouts, films, flip-chart } \\
\text { favor sitting in the front of the classroom }\end{array}$ \\
\hline Auditory learners & $\begin{array}{l}\text { discover information through listening and interpreting information by the means of } \\
\text { pitch, emphasis and speed } \\
\text { have a preference for the transfer of information through listening: to the spoken word, } \\
\text { of self or others, of sounds and noises }\end{array}$ \\
\hline $\begin{array}{l}\text { Kinesthetic } \\
\text { learners }\end{array}$ & $\begin{array}{l}\text { learn best with and active "hands-on" approach } \\
\text { have a preference for physical experience: touching, feeling, holding, doing, practical } \\
\text { hands-on experiences }\end{array}$ \\
\hline
\end{tabular}

Source: Abbas P. G. (2012).

Learners were expected to indicate how much they agree with each item on a scale from 1 to 5 when they learn English. Each number notes certain measurement such as: (5) strongly agree, (4) agree, (3) undecided, (2) disagree and (1) strongly disagree.

Besides, the following opened questions were also asked to learners during an interview in order to gather their opinions on Reid's second hypothesis:

1. Have you ever felt unhappy or frustrated in class because your teacher's teaching style was different to your learning style?

2. When the teacher teaches in a different style to your learning style, does it affect your learning? If yes, how?

For assessing teaching styles, a modified version of PLSPQ was used and administrated to English teachers.

\section{3. STATISTICAL ANALYSIS}

After computerizing the data collected with Excel 2019, statistical analysis has been processed with R4.0.2 software, package "MASS". Qualitative data analysis was used to find consistent patterns in the various perspectives revealed in the questionnaires data (Hounnou Azoua, 2020). For quantitative data, the analysis has consisted in descriptive statistics calculation (Shousha, 2018).

\section{FINDINGS AND DISCUSSION 4.1. Findings presentation}

\subsubsection{Data from questionnaires addressed to learners}

The analysis revealed that the mean score of the visual style was 18.75 , which means the learners were most likely to prefer to learn English with the help of visual materials. Kinesthetic (16.78) and auditory learning style (15.9) were also preferred like learning styles. Even though the former learning style was also a major one among learners, it appears to be less favored than visual and kinesthetic styles. Also, it was shown that there were learners with one, two, three or no learning style. The majority of learners (95.2\%) has more than one major learning style.
Moreover, it was proved that thirty-seven learners, that is $90.24 \%$ were confirmed to be visual style owners. Learning numbering thirty-four, that is $82.92 \%$ belong to kinesthetic style owner group and thirty-two, it is $78.04 \%$ learners were described as auditory learners. Overall, the most preferred major style is the Visual one. Kinesthetic and auditory styles follow.

\subsubsection{Data from questionnaires addressed to teachers}

The study showed that the major teaching styles of teachers were kinesthetic and visual styles. Auditory style appeared to be a minor one. In fact, the mean score of kinesthetic style was 14.9 whereas the ones of Visual and Auditory styles practice were respectively 13.6 and 12.9 . It was noted also that the majority of teachers, that is $70 \%$ has two teaching styles. Only one teacher off the ten investigated combined three teaching styles to run class. They all have a teaching style at least.

\subsubsection{Data from interview with learners}

Concerning the question "Have you ever felt unhappy or frustrated in class because your teacher's teaching style was different to your learning style?" it was revealed that a large proportion of learners $85.4 \%$ was frustrated in class whenever their teachers' teaching style was different from their learning style. Furthermore, the majority, $63.3 \%$ attested that such practice influenced their learning process against $31.7 \%$. The different responses showed that learners' learning is negatively affected when they were victims of mismatch between their styles and their teachers' one. As negative impacts, most of them, that is $73.2 \%$ get bored of the subject and lose interest in the lesson (65.8\%). 36.6\% feel very uncomfortable, $31.7 \%$ find it difficult to concentrate, $14.6 \%$ find the lesson stressful, $61 \%$ learn less or even nothing and consequently want to give up $(21.9 \%)$.

\subsection{DISCUSSION}

Throughout the study, it was shown that only one learner was found having no major learning style in the present study. The forty remaining learners, it is $97.6 \%$ were identified with at least one learning style. 
The percentage of learners increases with the number of identified major styles. The most predominant group appears to be learners with three major learning styles $(65.9 \%)$. These observations prove that the EFL learners investigated were aware enough of the way they were taught and the styles they want to be taught. The results corroborate Bhagat et al. (2015) who find that there are significant increases in the number of students who are aware of Learning Styles and that they know what styles fit with them. It was noticeable that most of learners are likely to prefer to learn English language with the help of visual and kinesthetic materials than auditory materials although visual, kinesthetic and auditory styles are all revealed to be of major type.

As a consequence, Reid's first hypothesis (that all students have their own learning styles and learning strengths and weaknesses) was found to be true for learners of the study. These results are very important since visuals use help learners to experience more what they learn and they make learning process successful. Such observations are similar to Jang and Kim (2014), Dong and Goh (2015), who think that educational videos are generally useful, and are of good value in medical education. Furthermore, Owolabi and Bekel (2021) confirmed that in COVID-19 pandemic context, implementing innovative educational technologies in teaching of anatomy and basic medical science has been of important use. So one can conclude that Videos are a vital educational resource and are based on the need to have a collection of resources of various types. On another hand, it is noteworthy that all the teachers also had identifiable teaching styles. They strongly favored kinesthetic teaching style (14.9), favored visual style (13.6) and disfavored auditory teaching style (12.9). The majority of them have two teaching styles (70\%). This teaching strategy that combine styles is very useful because it helps students to break monotony and help teacher to maintain a constant motivation all along the class as have shown Azoua Hounnou and al. (2020).

The comparison of teaching and learning styles revealed that both learners and teachers favored visual and kinesthetic style. However, most teachers prefer teaching by doing kinesthetic activities than visual activities whereas most learners prefer to be taught by visual materials than kinesthetic materials. Moreover, learners favor auditory style (even less than visual and kinesthetic styles) while teachers disfavor that teaching style.

Therefore, a mismatch arises between learning and teaching styles regarding all the three styles. Furthermore, interviews reveal that more than four fiftieth (approximately 85.4\%) of learners feel very unhappy or frustrated when the teacher's style differ from their learning style and $68.3 \%$ said the difference negatively affects their learning of EFL.
As a result, one can say that the mismatch between learning and teaching styles do negatively impact learners' learning. When it happens, most of learners are discouraged and got bored. They prefer study another subject during English course. Over time, they lose interest in studying the language and learn less or even nothing. Sometimes, some learners want to give up because they found their efforts fruitless. Such conclusion was found by Felder and Spurlin, (2005), Matthew (2001) using the case of EFL learners and teachers at a university of Hong Kong. Also, Abbas (2012b) concluded that without suitability between students' styles and teachers' styles, clashes would appear and would affect students' learning potential and their attitudes toward learning.

All these conclusions considered, Reid's second hypothesis is confirmed in the case study of learners and teachers of Benin secondary school. However, this finding is of course limited to the context of this study, and does not do much to be broadened to the international scope of the hypothesis.

\section{CONCLUSION}

This study refers to the analysis of the suitability or the unsuitability between teaching and learning styles in the context of EFL in municipality of Parakou (Benin). It's found that learners as teachers were more likely to prefer visual and kinesthetic styles than auditory style. There was a mismatch between teaching and learning styles regarding the three styles. Such difference has negatives impacts on teaching learning process and therefore hamper students' achievement. Teachers were strongly suggested to identify their own teaching styles and assess their learners' styles at the beginning of the year. Discovering their learning styles and be aware of what they mean will allow learners to determine their own personal strengths and weaknesses and learn from them.

\section{REFERENCES}

- Abbas, P. G. (2012b). A match or mismatch between learning styles of the learners and teaching styles of the teachers. Modern Education and Computer Science, 51-60. Published online December 2012 in MECS http://www.mecs-press.org/

- Abbas, P. G. (2012a). Visual, Auditory, Kinesthetic Learning Styles and Their Impacts on English Language Teaching. Journal of Studies in Education, 2(1), Published http://dx.doi.org/10.5296/jse.v2i1.1007

- Alaraj, M.M. (2016). EFL Acquisition External Problems and Difficulties: An Investigative Interview to Examine Saudi Students' Thoughts and Feelings. Journal of Language Teaching and Research, 7(3), 484-490. DOI: http://dx.doi.org/10.17507/jltr.0703.07

- $\quad$ Anderson, R. C. (1995). Cognitive psychology and its implications. 4th ed. New York: Freeman.

- Arshad, M., Attari, Z. H., \& Elahi, E. (2012). Impact of parents' profession on their children's learning 
English in Pakistan. International Journal of Learning \& Development, 2(1), 426-437.

- $\quad$ Azoua, H., M., Adjoha, B. Oguidi, D. C. J-C. (2020). Innovative Tips and Astuces to Acquire English as a Foreign Language in Parakou Secondary Schools. Annals of Language and Literature, 4(2), 11-16

- $\quad$ Bhagat, A., Vyas, R., \& Singh, T. (2015). Students awareness of learning styles and their perceptions to a mixed method approach for learning. International Journal of Applied and Basic Medical Research, 5(Suppl 1), S58.

- Lee, B., \& Kim, H. (2014). What Can We Learn from Our Learners' Learning Styles?. English Language Teaching, 7(9), 118-131.

- Damrongpanit, S. (2014). An Interaction of learning and teaching styles influencing mathematic achievements of ninth-grade students: A multilevel approach. Educational Research and Reviews, 9(19), 771-779.

- Dong, C., Goh, P.S. (2015). Twelve tips for the effective use of videos in medical education. Med Teach, 37(2); 140-145.

- Entwistle N., Hanley., \& M Hounsell, D. (1979). "Identifying distinctive approaches to studying". Higher Education, 8, 365-380.

- Entwistle, N., McCune, V., \& Walker, P. (2001). Conceptions, styles, and approaches within higher education: Analytic abstractions, everyday life. In R. J. Sternberg \& L-F Zhang (Eds.) (2001). Perspectives on thinking, learning and cognitive styles. (pp. 103136) Mahwah, NJ: Lawrence Erlbaum, 40

- Faryadi, Q. (2012). A Guide to Effective Teaching. Negeri Sembilan: USIM Publisher.

- Felder R. M., \& Spurlin J. E. (2005). Applications, reliability and validity of the Index of Learning Styles. International Journal of Engineering Education, 21(1), 103-112.

- Ford, N., \& Chen, S. Y. (2001). "Matching/mismatching revisited: An empirical study of learning and teaching styles". British Journal of Educational Technology, 32(1), 5-22.

- Gan, Z. (2012). Understanding L2 speaking problems: Implications for ESL curriculum development in a teacher training institution in Hong Kong. Australian Journal of Teacher Education (Online), 37(1), 43-59.

- Grasha, A.F. (2002). Teaching with Styles: A Practical Guide to Enhancing Learning by Understanding Teaching and Learning Styles. San Bernarino, CA: Alliance

- Hayes, J., \& Allinson, C. W. (1997). Learning styles and training and development in work settings: Lessons from educational research. Educational Psychology, 17(1-2), 185-193.

- Jang, H. W., \& Kim, K. J. (2014). Use of online clinical videos for clinical skills training for medical students: benefits and challenges. BMC medical education, 14(1), 1-6.
- Kaplan, E. J., \& Kies, D. A. (1995). Teaching styles and learning styles: Which came first?. Journal of Instructional Psychology, 22(1), 29.

- $\quad$ Kasim, T. S. A. T., \& Abdurajak, F. S. (2018). Issues and challenges in teaching and learning: an analysis of Islamic education novice teachers' practices. International Journal of Education, Psychology and Counselling, 3(12), 99-109.

- Kazemi, A., \& Soleimani, N. (2016). On the Relationship between EFL Teachers' Classroom Management Approaches and the Dominant Teaching Style: A Mixed Method Study. Iranian Journal of Language Teaching Research, 4(2), 87-103.

- Mappiasse, S. S., \& Sihes, A. J. B. (2014). Evaluation of English as a Foreign Language and Its Curriculum in Indonesia: A Review. English Language Teaching, 7(10), 113-122.

- McKeachie, W. J. (1995, November). Learning styles can become learning strategies. In The National Teaching and Learning Forum (Vol. 4, No. 6, pp. 1$3)$.

- Noonan, F. J. (2005). Helping EFL students improve their spoken English. The Internet TESL Journal, 11(7).

- Owolabi, J., \& Bekele, A. (2021). Implementation of Innovative Educational Technologies in Teaching of Anatomy and Basic Medical Sciences During the COVID-19 Pandemic in a Developing Country: The COVID-19 Silver Lining?. Advances in Medical Education and Practice, 12, 619.

- Zare, P. (2012). Language learning strategies among EFL/ESL learners: A review of literature. International Journal of Humanities and Social Science, 2(5), 162-169.

- $\quad$ Reid, J. M. (1987). The learning style preferences of ESL students. TESOL quarterly, 21(1), 87-111.

- $\quad$ Smith, L. H., \& Renzulli, J. S. (1984). Learning style preferences: A practical approach for classroom teachers. Theory into practice, 23(1), 44-50.

- Damrongpanit, S., \& Reungtragul, A. (2013). Matching of learning styles and teaching styles: Advantage and disadvantage on ninth-grade students academic achievements. Educational Research and Reviews, 8(20), 1937-1947.

- Heydarnejad, T., Hosseini Fatemi, A., \& Ghonsooly, B. (2017). An exploration of EFL teachers' teaching styles and emotions. Journal of Applied Linguistics and Language Research, 4(2), 26-46.

- Visser, S., McChlery, S., \& Vreken, N. (2006). Teaching styles versus learning styles in the accounting sciences in the United Kingdom and South Africa: a comparative analysis. Meditari accountancy research.

- Woolhouse, M., \& Blaire, T. (2003). Learning styles and retention and achievement on a two-year A-level programme in a further education college. Journal of Further and Higher Education, 27(3), 257-269.

Cite This Article: Hounnou Azoua Mathias (2022). Reflections on the Suitability and Unsuitability of English as a Foreign Langauge Teaching and Learning Styles in Benin. EAS J Humanit Cult Stud, 4(1), 1-6. 